\title{
POTENCY OF CV12 ACUPUNCTURE AS OBESITY PREVENTION THROUGH MODULATION OF $\alpha$ AND $\beta$ ESTROGEN RECEPTORS EXPRESSION ON THE ADIPOSE TISSUE OF OVARIECTOMIZED MICE
}

\author{
Purwo Sri Rejeki ${ }^{1}$, Sundari Indah Wiyasihati ${ }^{1}$, Atika $^{2}$ \\ ${ }^{1}$ Department of Physiology, ${ }^{2}$ Department of Public Health, \\ Faculty of Medicine, UniversitasAirlangga
}

\begin{abstract}
ABSTRAK
Penelitian ini bertujuan untuk mengetahui potensi CV 12 akupunktur sebagai pencegahan kenaikan berat badan di ovariectomizedmice (OVX). Perempuan tikus galur BALB/c, 28 tikus, 3-4 minggu, 25-35 gram dibagi menjadi empat kelompok; yaitu $K 1$ ( $n=8$, palsu dan injeksi vehiculum), K2 ( $n=8$, OVX dan injeksi vehiculum), K3 ( $n=7$, OVX dan injeksi estrogen intraperitoneal $10 \mathrm{mg} / \mathrm{kg} / \mathrm{hari})$ dan $\mathrm{K} 4$ ( $\mathrm{n}=6$, OVX dan CV12 akupunktur dengan frekuensi $2 \mathrm{~Hz}$ di $10 \mathrm{~mA}$ terus menerus lonjakan gelombang saat ini). Injection dan akupunktur diberikan setiap hari selama empat minggu. perubahan berat badan di K1 $(0,75 \pm 2,8)$ gram, K2 (2.71 \pm 2 ,4) gram, $K 3(0.71 \pm 0.95) \mathrm{g}$ dan $K 4(0.93 \pm 2.40)$ gram dengan perbedaan yang signifikan dalam $K 2$ dan $K 4(p=0,011)$. Ekspresi $\alpha$ reseptor di $K 1(12,25 \pm 2,96), K 2(5.43 \pm 2.64), K 3(18,86 \pm 1,57), K 4(17 \pm 2,00)$ dengan perbedaan yang signifikan dengan K2 K1, K3 dan K4 dengan $p<0,05$. Ekspresi $\beta$ reseptor di K1 (11,38 $\pm 1,92), K 2(4 \pm 1,41), K 3(16.86 \pm 1.86), K 4(14,17 \pm$ 5 ,24) dengan signifikan berbeda ekspresi a reseptor di massa lemak visceral pada kelompok K2 ke K1, K3 dan K4 dengan $p<0,05$. CV 12 acupuncture increases ekspresi $\alpha$ dan $\beta$ reseptor estrogen di jaringan adiposa viseral tikus OVX ekuivalen dan mampu mencegah kenaikan berat badan karena penarikan estrogen. Hal ini berpotensi dapat digunakan sebagai salah satu pencegahan manajemen obesitas menopause. (FMI 2017;53:24-28)
\end{abstract}

Kata kunci: tikus, ovariektomi, akupunktur CV 12, ER , ERß

\begin{abstract}
This study aims to determine the potency of $\mathrm{CV} 12$ acupuncture as prevention of weight gain in ovariectomizedmice (OVX). Female mice strain $B A L B / c, 28$ mice, 3-4 weeks, 25-35 grams were divided into four groups; namely K1 $(n=8$, sham and vehiculum injection), $K 2(n=8$, OVX and vehiculum injection), $K 3(n=7$, OVX and injection of estrogen intraperitoneal $10 \mathrm{mg} / \mathrm{kg} / \mathrm{day})$ and $\mathrm{K} 4$ $(n=6, O V X$ and $\mathrm{CV} 12$ acupuncture with a frequency of $2 \mathrm{~Hz}$ in $10 \mathrm{~mA}$ of continuous spike current wave).Injection and acupuncture given every day for four weeks. Weight change in $K 1(0.75 \pm 2.8)$ grams, K2 (2.71 \pm 2.4$)$ grams, K3 $(0.71 \pm 0.95) \mathrm{g}$ and $\mathrm{K} 4(0.93 \pm$ 2.40) gram with a significant difference in the $K 2$ and $K 4(p=0.011)$. $\alpha$ receptor expression in $K 1(12.25 \pm 2.96), K 2(5.43 \pm 2.64)$, $K 3(18.86 \pm 1.57), K 4(17 \pm 2.00)$ with a significant difference to the $K 2 \mathrm{~K} 1, \mathrm{~K} 3$ and $K 4$ with $p<0.05$. $\beta$ receptor expression in K1 (11.38 \pm 1.92$), K 2(4 \pm 1.41), K 3(16.86 \pm 1.86), K 4(14.17 \pm 5.24)$ with significantly different $\alpha$ receptor expression in visceral fat mass on the group $K 2$ to $K 1, K 3$ and $K 4$ with $p<0.05$. CV 12 acupuncture increases the expression of $\alpha$ and $\beta$ estrogen receptor in visceral adipose tissue of OVX mice equivalently and able to prevent the increase of weight due to the estrogen withdrawal. This point could potentially be used as one of the management ofobesity prevention in menopause. (FMI 2017;53:24-28)
\end{abstract}

Keywords: mice, ovariectomy, acupuncture CV 12, ER $\alpha, E R \beta$

Correspondence: Purwo Sri Rejeki, Department of Physiology, Faculty of Medicine, Universitas Airlangga, Jalan Prof Dr Moestopo No.47, Surabaya, Indonesia. Email: purwo_faal@yahoo.com

\section{INTRODUCTION}

Obesity is an epidemic disease that has struck the world. Based on data of $\mathrm{WHO}$, one billion people worldwide were overweight, and at least 300 million are clinically obese diagnosed (Mori et al., 2008). The populations that experiencing the rapid incrementof obesity prevalence is the post-menopausal women (Allende-Vigo, 2008; Geer and Shen, 2009). Obesity in women is expected because of the withdrawal of estrogen levels in the blood.
Estrogen receptor activation produce a linear result of the obesity prevention and treatment. Estrogen receptor activation increases the expression of uncouple proteins 1 and 2 thus increasing thermogenesis and heat output. Activation of estrogen also decreases the expression of SREBP and lipoprotein lipase which acts on lipogenesis resulting in decreased synthesis of adipose mass (Yepuru et al., 2010). Therapy of estrogen hormone replacement in postmenopausal women known to affect the initiation of cancer in the uterus and should not be 
given to women who still have a uterus. It also increases the risk for stroke, blood clots, breast cancer, gallstones, ovarian cancer and dementia. The addition of progestin in hormone replacement therapy slightly reduce the risk but raise the prices. Thus it is necessary to develop the appropriate modalities of therapyto address this.

Acupuncture is one of treatment method which began to be developed throughout the world. In some previous studies, acupuncture proved to modulate leptin in models of polycystic ovary syndrome mice. Acupuncture also play a role ofpreventing weight gain in mice exposed to a high-fat diet or the ovariectomy mice. This study aims to determine the effects of acupuncture on the expression of estrogen receptors in visceral fat tissue that is still unsolved.

\section{MATERIALS AND METHODS}

Twenty eightfemale mice (BALB/c) aged 3-4 weeks old weighing 25-35 grams were purchased from Pusat Veterinaria Farma Surabaya. Animals were kept at 25$30 \mathrm{oC}$ room temperature, with free access to food and water and a 12-hour light/dark cycle.The mice were divided into four groups: sham + vehiculum injection; OVX + vehiculum injection; OVX + intraperitoneal injection of estrogen $(10 \mathrm{mg} / \mathrm{kg} /$ day $)$; and OVX $+\mathrm{CV}$ 12 acupuncture.

All the procedures performed were approved by the Research Ethics Commissions of Faculty of Veterinary Medicine, Universitas Airlangga. Mice were ovariectomized by the dorsal approach under general anesthesia. Once anesthetized, abdominal incision was performed, the fallopian tubes were ligated, the ovaries were removed, and the incision was closed with suture procedure. Sham surgery was performed with the same abdominal surgery without removal of the ovaries. Recovery period for each mouse was seven days.

Estrogen ( $\beta$-estradiol;Sigma Aldrich) was diluted in dimethyl sulfoxide (DMSO 78; Sigma Aldrich) for intraperitoneal injection (10 mg/kg/day) (Modderet al., 2004). DMSO 78solution was used forvehiculum injection. Estrogen and vehiculum treatments were administered 0,5 mleveryday for one month.

The acupuncture point for AES treatment was CV 12 (中脘 or zhōng wăn) located in the midline of the body, midway between xiphoid process and umbilicus. Needles with a length of 0.5 inch or $1.25 \mathrm{~cm}$ were inserted $2 \mathrm{~mm}$ depthat an angle of 85 degrees.Stimulation of $2 \mathrm{~Hz}, 10 \mathrm{~mA}$ continuous spike waveswas administered for ten minutes every day for one month without anesthesia. Acupuncture instrument used in this study was electro stimulator (AES-04) produced by the Faculty of Science and Technology UNAIR. The positive electrode was connected to electro stimulator while negative electrodes was connected on the ground.

All mice were weighed before and after one month treatments. At the end of the experiment, the mice were anesthetized and the abdomen was incised. Omentum fat, reproductive organs and all intraperitoneal organs were removed and the mice were decapitated.The visceral abdominal fat mass was separated, weighed and examined for the expression of estrogen receptors $\alpha$ and $\beta$ by immunohistochemistry.

Statistical comparisons were performed by randomizeddesign ANOVA using Statistical Package for the Social Sciences (SPSS) software version 16. The analysis used wasdescriptive and analytic/inferential analysis. Inferential analysis was used to look at the test of adipose differential for each group, differential express-ion of $\alpha$ and $\beta$ estrogen receptor in each group, as well as the correlation between adipose mass with expression of $\alpha$ and $\beta$ estrogen receptor.

\section{RESULTS}

Pre-treatment weight loss can be observed in Table 1. In tests of homogeneity variation of initial body weight group, the value obtained was $0.436(>0.05)$, which means that the data were normally distributed.

Table 1. Initial body weight in all four groups

\begin{tabular}{|c|c|c|c|c|}
\hline \multirow[t]{2}{*}{ Group } & \multirow[t]{2}{*}{$\mathrm{n}$} & \multicolumn{3}{|c|}{ Body Weight (gram) } \\
\hline & & Mean \pm SD & Min & Max \\
\hline Sham + vehiculum & 8 & $27.00 \pm 5.16$ & 23 & 39 \\
\hline OVX+vehiculum & 7 & $26.29 \pm 3.15$ & 20 & 29 \\
\hline OVX + estrogen & 7 & $25.14 \pm 2.67$ & 21 & 29 \\
\hline $\mathrm{OVX}+$ acupuncture & 6 & $28.83 \pm 1.94$ & 26 & 31 \\
\hline
\end{tabular}

Statistical descriptive of weight after treatment can be seen in Table 2. The results of the post-treatment weight measurements used for test the homogeneity of variances and obtained $p=0.918$, which means that the data was homogeneous.

Table 2. Weight after treatment in all four groups

\begin{tabular}{lcccc}
\hline \multicolumn{1}{c}{ Group } & $\mathrm{n}$ & \multicolumn{3}{c}{ Weight (gram) } \\
\cline { 4 - 5 } & & Mean \pm SD & Min & Max \\
\hline Sham+vehiculum & 8 & $26.63 \pm 2.67$ & 24 & 30 \\
OVX+vehiculum & 7 & $26.29 \pm 3.15$ & 26 & 32 \\
OVX + estrogen & 7 & $25.14 \pm 2.67$ & 22 & 31 \\
OVX + acupuncture & 6 & $28.17 \pm 2.14$ & 25 & 30 \\
\hline
\end{tabular}


Change (delta) of weight is the weight difference of the post-treatment weight reduced by pretreatment weight. Detailed data can be seen in Table 3. The normality test was obtained $p=0.73$. Thus, it could be concluded that the group distribution was normal and could be used at ANOVA test. The ANOVA result was $p=0.76$, means there was no different in all four groupgroup.

Table 3. Change (delta) of initial body weight in all four groups

\begin{tabular}{|c|c|c|c|c|c|}
\hline \multirow[b]{2}{*}{ Group } & \multirow[b]{2}{*}{$\mathrm{n}$} & \multicolumn{3}{|c|}{ Weight (gram) } & \multirow{2}{*}{$\begin{array}{l}\text { One way } \\
\text { Anova }\end{array}$} \\
\hline & & Mean \pm SD & Min & Max & \\
\hline Sham+vehiculum & 8 & $0.75 \pm 2.82$ & -4 & 4 & $F=2.594$ \\
\hline OVX+vehiculum & 7 & $2.71 \pm 2.43$ & 0 & 2 & $\mathrm{p}=0.076$ \\
\hline OVX + estrogen & 7 & $0.71 \pm 0.95$ & -1 & 2 & \\
\hline OVX + acupuncture & 6 & $-0.67 \pm 2.07$ & -3 & 3 & \\
\hline
\end{tabular}

Weight change is a problem that is often complained by women who reach menopause. Decreased estrogen levels as a result od discontinued producing of estrogen in the blood thought to be one reason for the increase in weight in this phase. Selection of female mice with the age of 3-4 weeks with weight of 25-35 grams was the age range of adult mice that could serve as a model of menopause by removing ovaries (ovariectomy $=\mathrm{OVX}$ ).

Mice in the $\mathrm{K} 1$ group was performed the dorsal abdominal opening and then closed again without took the ovaries. Results that were expected in this group was the image of mice that had normal levels of estrogen due to the intact ovaries. Mice in K2 group got ovariectomy after one-weekperiod of adaptation. A week later then given estrogen injection vehiculumas the treatment with the same total volume injected into the K3.Resultsthat were expected in this group was the image of mice that had underwent menopause without estrogen replacement therapy or other activities that caused boost of estrogen levels in the blood.

In K3 group, mice performed ovariectomy after oneweekperiod of adaptation and then given estrogen injections with predetermined volume which was dose of $10 \mathrm{mg} / \mathrm{kg} / \mathrm{day}$ for four weeks. Resultsthat were expected in this group was mice underwent menopause but had estrogen hormone replacement therapy. K4 group mice was treated as menopause similar to $\mathrm{K} 2$ and $\mathrm{K} 3$ groups butthis group was expected to provide an overview of menopause mice that received acupuncture therapy.

From the data of weight after treatment and delta of weight above, although there was no significant difference in the group of 1,2, 3 and 4 , but it could be seen that mice in the $\mathrm{K} 2$ group had the highest weight gain compared to other groups. It indicated that the decrease of estrogen had a big role in the incensement of body weight in ovariectomized mice. Group 1 and 2 had a weight gain that was lower than $\mathrm{K} 1$, because these two groups had estrogen level that was equivalent to condition of reproductive mice, which in the $\mathrm{K} 1$ group had intact ovaries; while at K3, estrogens obtained from the external through the injection maintaining internal estrogen levels.

$\alpha$ Estrogen receptor is receptor that is expressed in almost all tissues of the body in both adipose tissue and muscle. This study aims to know $\alpha$ receptor expression in visceral adipose tissue. For the expression of the $\alpha$ receptor $(E R \alpha)$ in each group can be seen in Table 4.

Table 4. Expression of Receptor $\alpha$ in adipose Network

\begin{tabular}{|c|c|c|c|c|c|}
\hline \multirow[t]{2}{*}{ Group } & \multirow[t]{2}{*}{$\mathrm{n}$} & \multicolumn{3}{|l|}{ Expression } & \multirow{2}{*}{$\begin{array}{l}\text { One way } \\
\text { Anova }\end{array}$} \\
\hline & & Mean \pm SD & Min & Max & \\
\hline Sham+vehiculum & 8 & $12.25 \pm 2.96^{\mathrm{a}}$ & 7 & 14 & $\mathrm{~F}=2.179$ \\
\hline OVX+vehiculum & 7 & $5.43 \pm 2.64$ & 2 & 9 & $\mathrm{p}=0.031$ \\
\hline OVX + estrogen & 7 & $18.86 \pm 1.57^{a . b}$ & 16 & 21 & \\
\hline OVX + acupuncture & 6 & $17.00 \pm 2.00^{\mathrm{a}, \mathrm{b}}$ & 14 & 19 & \\
\hline
\end{tabular}

In Table 5 and Figure 1 we could see there were significant differences in the expression of ER $\alpha$ in $\mathrm{K} 1$ compared to $\mathrm{K} 2, \mathrm{~K} 1$ was also different than $\mathrm{K} 3$ and $\mathrm{K} 4$. $\mathrm{K} 2 \mathrm{ER} \alpha$ expression which was aresult of mice underwent menopause was different compared to all group. Meanwhile, no significant differences were found in $\mathrm{K} 3$ and $\mathrm{K} 4$. This indicates that in mice with intact ovaries and mice with injected estrogen the ER $\alpha$ expression was higher than the ovariectomied mice. Increased expression of ER $\alpha$ in $\mathrm{K} 4$ had the possibility of immense occurrence due to the same conditions in the $\mathrm{K} 1$ and $\mathrm{K} 3$, which indicated that $\mathrm{CV} 12$ acupuncture also modulate estrogen in the blood which was proven by its ability to modulate the ER $\alpha$ expression in visceral adipose tissue of mice.

Research by knockout (KO) theisoform of estrogen receptor showed the importance of this isoform in lipid and glucose homeostasis. The ER $\alpha$ of KO mice would show insulin resistance (Foryst et al., 2008). This suggests the importance ER $\alpha$ role in the prognosis of menopausal obesity and further metabolic syndrome.

Table 5. Expression of $\beta$ receptors in adipose Network

\begin{tabular}{|c|c|c|c|c|c|}
\hline \multirow[t]{2}{*}{ Group } & \multirow[t]{2}{*}{$\mathrm{n}$} & \multicolumn{3}{|c|}{ Expression } & \multirow{2}{*}{$\begin{array}{c}\text { One } \\
\text { way } \\
\text { Anova }\end{array}$} \\
\hline & & Mean+SD & Min & Max & \\
\hline Sham+vehiculum & 8 & $11.38 \pm 1.92^{\mathrm{a}}$ & 9 & 15 & $\mathrm{~F}=2.179$ \\
\hline OVX+vehiculum & 7 & $4.00 \pm 1.41^{\mathrm{b}}$ & 2 & 6 & $\mathrm{p}=0.031$ \\
\hline OVX + estrogen & 7 & $16.86 \pm 1.86^{\mathrm{c}}$ & 14 & 19 & \\
\hline OVX + acupuncture & 6 & $14.17 \pm 2.99^{c}$ & 10 & 19 & \\
\hline
\end{tabular}

$\beta$ Estrogen receptor (ER $\beta)$ was expressed on specific areas, even though it alsofound in adipose tissue, hypothalamus, lung and female reproductive tract. This 
study aims to know the ER $\beta$ expression in visceral adipose tissue. For ER $\beta$ expression in each group can be seen in Table 5 and Figure 2.

In Table 5 and Figure 2 we could see that the K2 group was different from the three other groups. K1 was different compared to K3 andK4, while no significant difference was found in $\mathrm{K} 3$ and $\mathrm{K} 4$. This indicates that in the acupuncture group experienced the conditions that similar to $\mathrm{K} 3$ resulting in increased expression of ER $\beta$.
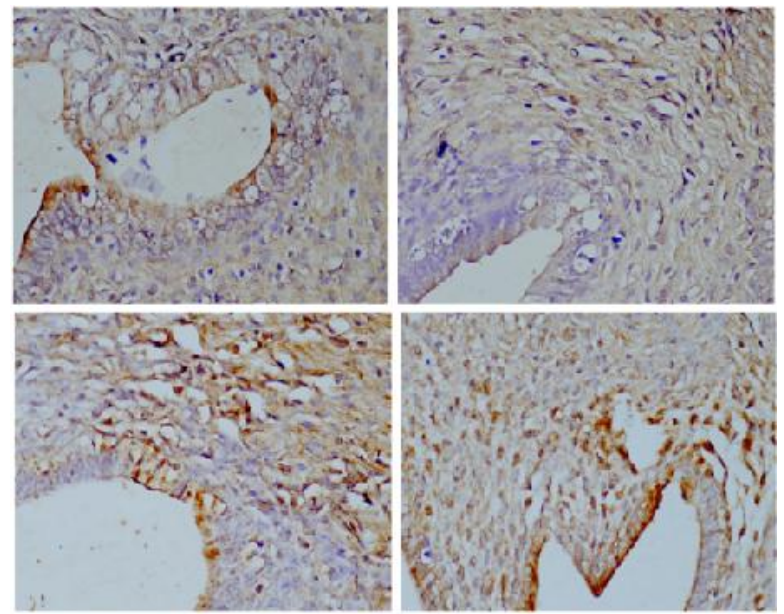

Fig. 1. Expression of $\alpha$ receptors in adipose tissue
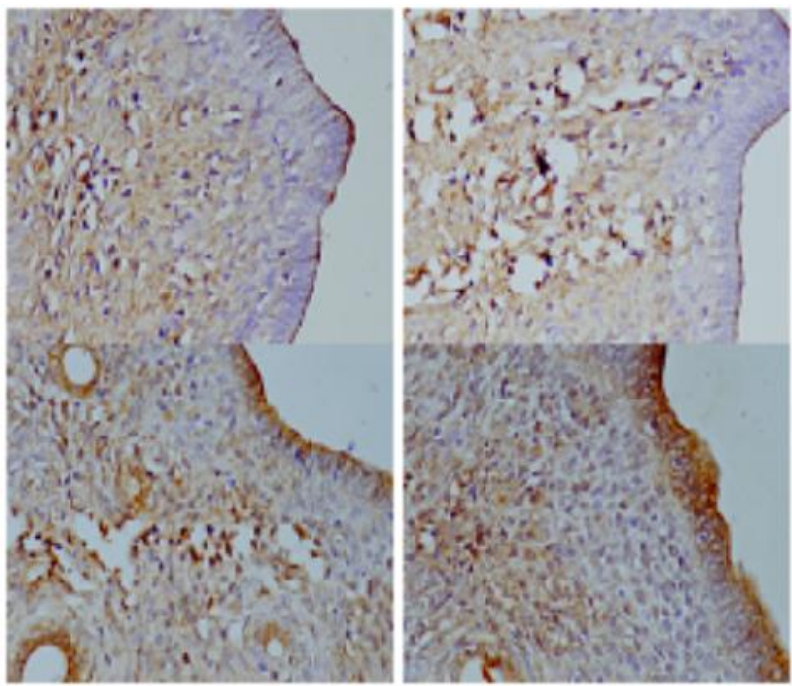

Fig. 2. The expression of $\beta$ receptor in adipose tissue

To see how big the adipose mass correlated to the expression of both types of receptors, the test was followed by correlation test. The resultcan be seen in Table 7
Table 6. Correlation of lipid mass and receptor expressions

\begin{tabular}{lcc}
\hline \multicolumn{1}{c}{ Group } & $\begin{array}{c}\text { Res } \alpha \\
\text { expression }\end{array}$ & $\begin{array}{c}\text { Res } \beta \\
\text { expression }\end{array}$ \\
\hline Sham + vehiculum & 0.128 & 0.152 \\
OVX + vehiculum & 0.302 & -0.215 \\
OVX + estrogen & 0.366 & $0.743^{*}$ \\
OVX + acupuncture & 0.387 & $0.852^{*}$ \\
\hline
\end{tabular}

From the table above, it showed that OVX group that were injected with estrogen and got CV12 acupuncture had significant correlation, with a value of $\mathrm{R}=0.743$ and $\mathrm{R}=0.852$. Previous research conducted by knockout (KO) the isoform of estrogen receptor showed the importance of this isoform in lipid and glucose homeostasis. In the ER $\alpha \mathrm{KO}$ mice would show insulin resistance while ER $\beta$ KO mice and given a high-fat diet showed the higher obesity possibility (Foryst et al., 2008).

Increased incidence of obesity after menopause, visceral obesity on andropause and in sex differences indicate the importance of hormonal metabolic diseases in regulating body weight (Allende-Vigo, 2008; Geer and Shen, 2009). Estrogen played an important role in increasing the use of energy, a decrease in adipogenesis and regulation of body weight (Ariazi and Jordan, 2006). The binding of estrogen to its receptor would decrease the reactive oxygen species (ROS) in the body that acted as an antioxidant, as it was known that ROS was one pathway in the pathophysiology of obesity.

Activation of estrogen also increased the IKB $\alpha$ protein expression which would inhibit NFKB incensement. Decreased levels of NFKB will reduce inflammation. In addition, decreased levels of NFKB activation will also reduce PPARG and C/EBPs thus there will be a decrease in adipogenesis. Decrease NFKB also reduce levels of TNF $\alpha$ and interleukin 6 that had impact on the production of cytokines by inflammatory cells (Miller et al., 2011).

In the prevention and treatment of obesity, targeting the ER $\beta$ is more profitable than ER $\alpha$. This is because the stimulation ER $\alpha$ will increase the risk of uterine cell growth and increase the probability of occurrence of uterine cancer. In the study conducted by Yepuru et al. (2010), activation of ER $\beta$ with selective ligand will increase the uncouple protein-1 and uncouple protein-2 by two to three fold. Both of these proteins are known to play a role in enhancing thermogenesis and increase the heat output. In addition, activation of this receptor also decreased the expression of PPARG that play a role in adipogenesis. 


\section{CONCLUSION}

CV12 Acupuncture prevent weight gain induced by ovariectomy. This was due to the ability of increasing the expression of $\alpha$ and $\beta$ estrogen receptor significantly.

\section{REFERENCES}

Allende-Vigo, MZ, 2008. P.R Health Sci J. 27, 190-195 Ariazi EA and Jordan VC, 2006.Curr Top Med Chem, 6, 203-215

Cypess AM, Lehman S, Williams G, Tal I, Rodman D, Goldfine AB, Kuo FC, Palmer EL, Tseng YH, Doria A, Kolodny GM and Kahn CR, 2009. N Engl J Med, 360, 1509-17

Flegal KM, Graubard BI, Williamson DF, Gail MH. 2005. Excess deaths associated with underweight, overweight, and obesity. JAMA 293:1861-1867

Foryst-Ludwig A, Clemenz M, Hohmann S, Hartge M, Sprang C, Frost N, Krikov M, et al., 2008. PloS Genet 4, e1000108

Friedman JM. 2004. Modern science versus the stigma of obesity.Nat Med 10:563-569.

Geer, EB and Shen W, 2009. Gen Med, Suppl,1, 60-75

Hadi H, 2005, Beban Ganda Masalah Gizi dan Implikasinya terhadap Kebijakan Pembangunan Kesehatan Nasional, Pidato pengukuhan Guru Besar, FKUGM, available at http://www.gizi.net/cgibin/berita/fullnews. cgi/newsid1109302893, 75841

Hill JO, Wyatt HR, Reed GW, Peters JC. 2003. Obesity and the environment: where do we go from here? Science 299:853-855.

Kopelman PG. 2000. Obesity as a medical problem. Nature 404:635- 643

Lacey JM, TershakovecAM and Foster JD, 2003. Acupuncture for the treatment of obesity: a review of the evidence, International Journal of Obesity 27, 419-427
Miller CN, Brown LM, Rayalam S, Della-Fera M, Baile CA, 2011. Estrogens, inflammation and obesity: an overview, Front. Biol., DOI 10.1007/s11515-0111174-y

Modder et al,. 2004. Dose-responseof estrogen on bone versus the uterus in ovariectomized mice, European Journal of Endocrinology, 157.503-10

Ma SX, 2004. Neurobiology of Acupuncture: Toward CAM, CAM;1(1)41-47

Mori MA, Arau'RJ, Reis FCG, Sgai DG, Fonseca RG, Barros CC, Merino VF, Passadore M, Barbosa AM, Ferrari B, Carayon P, Castro CHM, Shimuta SI, Luz J, Bascands JL, Schanstra JP, Even PC, Oliveira SM, Bader M, and PesqueroJB. 2008. Kinin B1 Receptor Deficiency Leads to Leptin Hypersensitivity and Resistance to Obesity. Diabetes 57:1491-1500

Ouyang H, Yin J, Wang Z, Pasricha PJ, and Chen JD., 2002. Electroacupuncture accelerates gastric emptying in association with changes in vagal activity. Am J PhysiolGastrointest Liver Physiol282: G390-396.

Weinstock RS, Dai H and Wadden TA, 1998. Diet and exercise in the treatment of obesity. Archives of Internal Medicine, 158(22), 2477-2483.

Somoza B, Guzma R, Cano V, Merino B, Ramos P, Di'ez-Fernandez C, Fernandez-Alfonso $\mathrm{MS}$, and Mariano RG. 2007. Induction of Cardiac Uncoupling Protein-2 Expression and Adenosine 5_Monophosphate-Activated Protein Kinase Phosphorylation during Early States of Diet-Induced Obesity in Mice.Endocrinology148: 924-931

Vickers A, Zollman C. ABC of complementary medicine: acupuncture. BMJ 1999; 319: 973-976.

Yepuru M, Eswaraka J, Kearbey JD, Barrett CM, Raghow S, Veverka KA, Miller DD, Dalton JT and Narayanan R, 2010. Molecular Bases of Disease: Estrogen Receptor? selective Ligands Alleviate High Fat Diet and Ovariectomy-induced Obesity in Mice, J,Biol. Chem, 285:31292-303. 